\title{
Index
}

Adam Smith in Beijing (Arrighi) 231, 243, 247

Africa 39-40, 53, 54, 234

alienation 56-57, 133, 202-203

America see United States

American exceptionalism

absence of socialism vs. fascism dynamic 165-166, 172, 176-177, 183-186

class and social status in 173-174, 176-178, 182

and global capitalist restoration 183-184

misinterpretations of 164-165

and plasticity $173,178,180-181$

social and economic characteristics of $32-33,156-157,180$

American Loan 37-38, 185

Amin, Samir 54, 231

Annales School 232

anti-trust legislation 47

Arrighi, Giovanni

Braudel's influence on 232, 240, 241-243, 244, 248, 249n13

on declining hegemons and

financialization 44-45, 237-238, 245

on embeddedness and declining

hegemony 238-240, 248n6

hegemony geometrical tool 236-237, 236

on imperialism 235-238, 236, 246

and the new economic sociology 243-244

Polanyi's influence on 232, 233-240, 245-247

on post-war capitalist reconstruction 245

quantitative/empirical grounding 241, 249n10

semi-periphery concept 240-241, 245

significance of 18

state-capital fusion in capitalism 242-243

transaction costs $244,245-246$ on US vs. British hegemony 18, 245, 247

see also hegemony; world-systems

theory

artificial intelligence 56-57, 162-163

Asia

East Asian financial crisis (1997) 2, 21, 52

exception to financialization trend 243

historical productive output 46

independence movements and revolutions 52-53

and multipolarity vs. globalization 9, 43, 54,55

and shifting hegemony 240-241, 245

and the US post-Second World War 39-40

Asian Infrastructure Investment Bank 54

Assange, Julian 131

Assyriology 66-68

Atlantic Charter 184, 188n7

atomic bomb $45-46$

Bairoch, Paul 46

balance of power 96, 97-98, 223-224, 248n3

'bancor' 83

Bandung conference (1955) 40, 54

The Bank Charter Act (1844) 31

banking complex see financial complex

Bank of England 96

banks

bankruptcies of 103, 111-112, 111, 112, 118

financialization of 44,117

see also 'Too Big to Fail' (TBTF)

Bauer, Otto 198

Bauman, Zygmunt 50

Becker, Gary 161

Beckett, Samuel 132 


\section{Behemoth 191}

Being and Consciousness 151

Bell, Daniel 166, 225

Belt and Road Initiative 54

Bennington Lectures

on American exceptionalism 32-33

'The Breakdown of the International

System' 8-9, 30-32, 45, 103

and the crisis of nineteenth century civilization 3, 27-29

in current economic discourse 21-23

genesis of 'The Present Age of

Transformation' 8, 23, 26, 45-46

and The Great Transformation 8, 27, $34-36,180$

historical perspective on the machine age $46-48$

on Keynes and the Bretton Woods system 36-38

long historical view twenty-first century capitalism 46-48

on the neoliberal counter-revolution 41-44

on the Russian Revolution 33-34

'The Trend Towards an Integrated Society' 8, 29-30

on the United States's rise to world power 38-41

see also The Great Transformation;

Polanyi, Karl

Bennington Lectures (follow up)

on the current neoliberal order 48-50

on the double movement today 50-51

on existential civilizational challenges 55-57

geopolitical shift to multipolar world 53-55

on the nation state in the global economy 52-53

on reactionary counter-movements 51-52

Berthoud, Gérald 265

Beveridge, William 37, 47

'Big Data' 131

Black and Scholes model 116

Block, Fred

critique of 80-81, 137-138, 170-171

influence on US left 2

on the New Deal 6, 170-171, 179, 182, $187,188 \mathrm{n} 6$

on Polanyi 17, 35, 248n2, 255

Bolshevik Revolution 33-34, 49-50, 144, $145,196,223,254$

Braudel, Ferdinand compatibility with Polanyi 244-245, $248 \mathrm{n} 15$

historical capitalism of 241-242, 244

influence on world-systems theorists 232 ,

240, 241-245, 248, 249n13

and the new economic sociology 244

Bretton Woods conference (1944) and post-

Second World War US 39

Bretton Woods financial order

collapse of and neoliberal ascendance

$158,224-225$

and inequality declines (1910-1970) 223

and Keynes 36-38, 40-41, 157

and liberal utopianism 164

Polanyi's opposition to $137,164-165$

vs. Polanyi's vision of socialism 15-16

and (re)embedded markets interpretation

$15,184-186$

restoration of capitalism 39, 184-185

and US rise to power $38-41,83$

see also gold standard

Brexit 7, 51

BRICS Development Bank 54

Brie, Michael 3, 5, 13-14, 16-17

Britain

absence of fascism in 172, 186

and Bretton Woods and Keynesianism 36-38

the Christian Left 204-205

coal miner's living conditions 255-256

embeddedness and the Lancashire cotton industry 239-240, 248n9

hegemony of (Arrighi) 237, 238-240, 246

Polanyi on foreign policy of 96

and transaction costs $244,245-246$

war economy as a social contract 37

post-Second World War socialism 184-185

British Labour Party 2, 26, 177, 185

Bücher, Karl 65

Bukharin, Nikolai 95-96

Bulletin of Atomic Scientists 54

bureaucratic surveillance 131, 133

Camus, Albert 132

Cangiani, Michele 81, 151, 189, 207, 256

Capital Assistance Program 114

Capital in the 21st Century

as complement to Polanyi 136, 211-212

failure to address neoliberalism 219-222

and false dualism of political and

economic 212-213

and global oligarchy dystopia 228-229 
Capital in the 21st Century (cont.)

indifference to transformations in industrial production 212, 225-229

naturalism problem in 212, 213-214

vs. Polanyi on income distribution shifts 222-225

r $>$ g law 17, 212-213, 214-220, 229

universalizing problem in 136

see also inequality; predistribution

capitalism

as a national phenomenon 52

as a specific social form $87,88,90$, 242-243

vs. civilization 57

collapse of liberal variant $46,47,154$, 166,211

vs. democracy $57,166-169,186$

and 'embedded liberalism' 83, 103, 120,

164,166

historical overview 46-48, 54, 63

and nature 55

Polanyi-Marx views compared $84-87$

post-war restorations of 39, 48, 183-184, 240-241, 245

and state intervention/planning 92-93, 137

Capital (Marx) 62, 79, 88, 107, 144, 230n3

Carlyle, Thomas 141

central banks

and classical economic theory 141-142

and International Clearing Union 37, 83

and predistribution 216

and social protection 78, 93-94

central planning (Mises on) 5, 148

Charpin, Dominique 67

Chicago School 9, 41, 48, 126, 158, 161

China 46, 53, 54

see also Asia

Churchill, Winston 26, 36-37, 45, 137

$\mathrm{CIO}$ (Congress of Industrial Organizations) $177,178-179$

civil society/Gesellschaft 35, 87-88, 89, 99, 152,202

classical liberalism 140-141, 148-150, 159

see also David Ricardo; Jean-Baptiste Say; naturalism

classical political economy

against state intervention 213-214

influence on Polanyi 10, 79, 81-82, 89

land, labour and money 11, 87

and Marx 87, 89-90

naturalist assumptions of 142-143, 159, 213-214 vs. neoclassical economics $81-82$

and Polanyi's critique of capitalism 87

and social consciousness shifts 144-145

Clayton Antitrust Act 188n4

climate change 55-56

Coase, Ronald 245

cold war 14, 42, 127, 240, 257-258

Cole, G.D.H. 2, 198

Columbia University project

on ancient Near Eastern economies 67-68

and the New Economic Archaeology 68-70

three systems of exchange 65-66

commodified money see money, commodified

commodities

circuits of 90,91

in classical political economy 82,87

fetishism in Marx 85, 150

and intentionality in classical political economy 82

'communist fiction' (Mises) 148, 149, 152, $163 n 2$

Community and Society (Tönnies) 87-88, 204

comparative advantage 81,86

complex society problem

in Mises 148-149

Polanyi's response to Mises 149-150

consciousness see social consciousness

Constitution of Liberty (Hayek) 42

consumers

balance with producers in US 156, 193

and financialization 44, 50, 227

and predistribution 216,218

and pricing as negotiation 24-25

and social-economic system specificity $40,226,228$

Continental Illinois Bank 103

Anti-Corn Law Bill (1846) 4

Corn Laws, repeal (Anti-Corn Law Bill of 1846) $4,31,80,91$

counter-movements

and consciousness shift after First World

War 144-146

and decreased inequality (1910-1970) 223

as disorganizing $147,167,178$

and fictitious commodities 146-147

liberal view of 139

limitations of 146-147, 153

and naturalism 154

and Owenism 152-153

reactionary $51-52,178$ 


\section{Index}

and social reproduction 167-168

and technological society $147,152-155$

see also the double movement; social

credit

protection

as a social relation $10-11,63-64,73$

and financialization 117

as property transfer and privatization 68 , $69,73-74,75$

(usury) and rural land tenure loss 69, 73,76

credit risk agencies 116, 120

critical rationalism 142

'crustacean nations'

defined as social protection 94

and the double movement 78-79

and money as a fictitious commodity

$11-12,94$

and nationalism 94

and the paradox of imperialism 100-101

vs. pluralistic international order 83-84

as resulting from gold standard 94

the US as 83

customs tariffs, as social protection 95

\section{Dahomey and the Slave Trade manuscript} 133-134

Dale, Gareth 187, 188n6, 232, 238, 250, 251, 255

on Arrighi 232, 238

on double-movement concept's relevance 138

and embeddedness 255

on interpretation of Polanyi 22, 84

on money $80-81$

and the New Deal 170, 171, 179

Polanyi's influences $13,35,86$

on the 'soft' Polanyi 251

Dalton, George 259

debt

annulments of in antiquity $10,67,69$, $73-74,76$

as a social relation $10-11,63-64,73$

Britain's to US after war 37-38

crises in ancient Rome 11, 73-74

and the gold standard-debt-austerity-

deflation cycle 61-62

management of in antiquity 65-66

and the mass consumption economy

crisis $6,44,226-228$

modern theorists vs. Ricardo on 73

as property transfer and privatization 68 , $69,73-74,75$

and the social character of money 89
Third World/Latin American debt crisis (1980s) 12, 104, 114, 120

De Cecco, Marcello 98, 99

decolonization 52-53, 234

deflation 37, 64, 92-93, 93-94, 141, 157

De Leon, Daniel 175, 187n2

democracy

vs. coercive predistribution 220

of liberty 173

and neoliberalism 45, 48, 219

'trilemma' 53

democratic socialism

and the breakdown of liberal utopianism 154

vs. capitalism and fascism 166, 169, 172, 179,190

vs. capitalist universalism $78-79$,

$183-186$

and 'crustacean nations' 78

and decommodification of land, labour and money 220

vs. free market ideologies 15

and integration of political-economic spheres 219-220

markets in 199

of Polanyi 78, 166, 172, 179, 185, 186

and welfarism in Polanyi interpretations 170-171

deregulation

as anti-reform 'double movement' 75

and disembedded financial institutions

103, 104-105, 109-111, 110, 120

neoliberal 12, 42, 75

as predistributive re-regulation $220-221$

Der Österreiche Volkswirt 176

Desai, Radhika 5, 9, 10, 11, 13, 79, 80, 102, 232, 248n 4

development $6,40,42,53-54,79,83$

development scholarship 83, 126

Dicey, A.V. 4, 13, 91

digital revolution 51, 56

disembedding

elastic band metaphor 137

and the naturalist fiction 143-144, 162

and Polanyian theory of history 166

process in Western civilization 29,62 , 74-77

Dissertation (Townsend) 140

Doomsday Clock 54

the double movement

in Arrighi 246

concept origin and meaning $4,13,147$, 154,189

defined 74-75 
the double movement (cont.)

deregulation as 75

and economic geography 252

and fictitious commodities $3,4,10$, 13-16, 29, 146-147

and financial institutions 102-103, 120

in free market liberalism 47, 50-51, 139, 166,190

and institutional paralysis 168

and the limits of counter-movements

146-147

misinterpretations of $137-138,168$

and Polanyi's theory of history 4,154 , 166-169

and post-war welfare states 50,53 , 157-158

and the precarity of work $45,51,56$, 216

reactionary forms of 7, 51-52, 75

and the 'reality of society' $13,127,163$

and the rise of fascism 200-201

and shifts in social consciousness 145-146, 154

and the social and market as sites of contestation 256

and social integration 35

and socialism $3,13-17,53,75$

and social protection 13-17, 146-147

of universal capitalism vs. nation states 78-79

in Western civilization 74-75

see also disembedding; embeddedness/ disembeddedness dialectic; financial complex; the reality of society; (re)embedded markets; social protection; spheres (political-economic separation); 'Too Big to Fail' (TBTF)

drones 131

Drucker, Peter 2, 86, 136, 178

Duczyńska, Ilona 25-27, 127, 255, 257

economic growth, and Keynes 38, 40-41, 43 'economistic fallacy' 136

Egypt 53

Eisenhower, Dwight David 39, 115-116

'embedded liberalism' 83, 103, 120, 164, 166

embeddedness

of banks in culture institutions 41,43 , 116,118

and declining hegemony (Britain) 239-240, 248n9

defined 102

of economic factors in a society $238-239$ and economic geography 251

vs. 'embedded liberalism' $83,103,120$,

164,166

and haute finance 105-106

and hegemony $164,238-240,248 n 6$

of markets in the new economic sociology 244

and Polanyi's personal dislocations 250

embeddedness/disembeddedness dialectic

and British coal miners 239-240

and institutional-geographical variability 263-264

and modes of integration 263-264, 266-267

and naturalism in liberal economic theory 144

of neoliberal era society into market mechanisms 162

scholarly applications of 135, 137-138, 144

variability and unevenness of 262-265

and variability of market 'freeness' 256

Essay on the Principle of Population

(Malthus) 140

exchange systems (in antiquity)

and debt and credit as a social relation 10-11, 63-64, 73

embedded trade and credit markets 65 , $66,67-68$

and mixed market and temple economies 68-69

reciprocity (gift exchanges) 65

redistributive temple and palace economies 65, 66-67

existentialism 132-133

exploitation

colonial 235, 246

of labour 52, 79, 86, 147, 162, 235

of nature 35

external payments deficits $37,40-41$

extinctions 55

failed states 53

false integration 29-30, 51-52

fascism

defeat of 45-46, 169

vs. democratic socialism $166,172,179$, 190

and the double movement $30,33,51-52$, $168-169$

and global oligarchy 228-229

and institutional deadlock 167-168, 172

and the United States 166, 176-177

and working class weakness 169 
FDIC (Federal Deposit Insurance Corporation) 117

Ferguson, Charles H. 116

fetishism 85, 150, 202

fiat money $76,78,88-89,92,93$

fictitious capital 12, 107, 108

fictitious commodities

in Arrighi 246

and classical political economy 81-82

defined 4, 10, 87, 107-108

the double movement 29, 146-147

and the fiction of self-regulating market

81-82, 90-91, 161, 215-221

vs. framework goods 199

and the impossibility of (re)-embedded markets 167

and incomes 146

as latent concept in Marx 84-85, 89-90

Marx-Polanyi comparison 215

as moral vs. historical argument 2, 5, $9-10,44,80,82$

vs. ordinary goods $63-64,88-91,146$

Polanyi vs. Marx on $87-88$

specific to the capitalist social system 87 , $88,90-91,197,225$

in Tönnies 87

financial capital

in Arrighi's analysis of imperialism 237-238, 243

fictitious 107-108

in the Great Depression and 2008 crisis 48

vs. industrial in Keynes 38

in the neoliberal era 43-44, 50

and Polanyi on Lenin 95-96

and power-brokering role of haute finance 106

share of GDP 43, 109, 117

see also financial complex; haute finance

financial complex

and bank bankruptcies 103, 111-112,

$111,112,118$

declining growth of 119,119

definition and evolution of in US

$115-120$

embedded with culture and credit

risk agencies $41,43,115-116,118$, 119-120

global aspects of 115,117

likened to military-industrial complex 115

vs. system $103,108-109,110-111$

value added by $118-119,119$

see also 'Too Big to Fail' (TBTF) financial crisis (2008)

compared to Great Depression 27, 44, $47-48$

and mass consumer economy 227-228

and neoliberal class interests 44, 217

and Polanyi resurgence 47-48

and shift in world growth to Asia 54

financial crisis, East Asian (1997) 2, 21, 52

Financial Crisis Inquiry Commission 44,

116-117

financialization

and declining hegemons (Arrighi) 44-45

and inequality 48

and neoliberalism 43-44, 55, 224-225

and personal debt 6,44

and social science disciplinary trends

251-252

and speculation 55,110

and the US as a 'crustacean nation' 83

financial sector

assets as proportion of GDP 43, 109, 112, 117-118

proportion of GDP increases vs. productive sector 116,117

and tax contribution of (value added) 118-119

Finley, Moses 67-68

'For a new West' (Polanyi) 240

Ford Foundation project 'Economic aspects of institutional growth' 257, 258

foreclosures, in antiquity (impact on governments) 63

framework goods 199

Frank, Andre Gunder 231, 249n11,

freedom

of conscience (inner freedom) 130-133

and leisure 38

neoliberal concept of $41,48,53$, 160-161

vs. overview/coordination 5, 149-152, $161,163 n 3$

problem of in industrial society 146 , $150-152,158$

Roosevelt on 39

and socialist vs. liberal 5, 14, 16, 17, 196-197, 202

as social responsibility 189

and technology 22, 131, 150-152

Freedom and Technology 14, 128, 133

freedom in a complex society critique of capitalism 193, 202-203

debate with Mises 197-200

and existential-social crisis 205-206 
freedom in a complex society (cont.)

and guild socialism 5, 150, 177, 198, 204, 219,233

methodology 190-193, 191

and the philosopheme of the murdered Chinese 202

as Polanyi's guiding question 148-152, 192-193, 205-208

and Polanyi's intellectual biography 193-197

as 'reality of a complex society' 17 , 198-200, 204-205

and the rise of fascism 200-201

and socialism as a moral-social imperative 196-197, 206-208

and social responsibility 202-204

society/community distinction 204-205

free market ideology

and disembeddedness of economy and society 62

'dismal science' 141

in economic liberalism 4, 15, 30, 62, 216 , 221, 255

and limits of creative social institutional role 139,141

naturalist fiction of 62-63

obfuscates analysis of capitalist society 85

see also naturalism; neoliberalism

free markets

and allocation of scarcity 126

and deregulation 42, 220-221

and the 'Geneva Group' 24, 48, 197

as mechanisms of expropriation 63-64

as predistributive $220-221$

social character of 63

and social instability 29-30

Friedman, Milton 41, 126, 158, 249n11

full employment 9, 21, 37, 42, 57, 216

Full Employment in a Free Society (Beveridge) 37

Furtado, Celso 46

futility thesis 142

Galarza, Ugarteche 12-13

Galbraith, John Kenneth 38, 43

Gallagher, John 96

Garfinkle, Steven 68

Gemeinwirtschaft (Mises) 148

General Agreement on Tariffs and Trade (GATT) 49

General Theory of Employment, Interest and Money (Keynes) 36

The Geneva School 48-50, 64-65, 161
The Geometry of Imperialism (Arrighi) 233

geopolitical economy 7, 78-79, 80, 81, 93, 98,232

Geopolitical Economy (Desai) 83, 232

geopolitics

of multi-polarity $9,53-55,79,83-84$, 257, 265-266

non-polarity of twenty-first century 53

German Historical School 232, 243

Germany 61-62, 97-99

Gladstone, William Ewart 96

Glass Steagall Act 103-104, 114, 120

global epidemics 131

globalization

chatword 241

and China and East Asia 43

and financialization 43-44

vs. internationalism $43,50,52-53$

and neoliberalism $42-43,48-50$

Polanyi/Arrighi 231

and transnational corporations 43

'trilemma' 53

Goldfrank, W.L. 231-232, 248n2

Goldman Sachs 105, 110, 112, 113, 115, 117

gold standard

in Arrighi 234, 237

and central banks 78, 94, 141-142, 224

in classical economic theory 141-142

collapse 11, 41, 96-101, 103, 234

and deflation 61, 64

and disembedding of liberal financial

system 103

and the dollar 103-104

and fictitious commodities 78, 81, 93

and the Great Depression 224

and haute finance 97

and international system after First

World War 28, 30-32, 61, 234

Keynes on 36, 92

and price-specie flow mechanism 142

self-regulating market fiction of 100

stability vs. volatility of 63-64, 98-99

and the [post-]Second World War order 165,184

Gomez, Ana 125

Gompers, Samuel 188n4

Graeber, David 136

Gramsci, Antonio 144

Granovetter, Mark 251

Great Depression

and American exceptionalism 32-33, 38, $157,165,175-177$ 
causes of $62,225,226$

compared to 2008 financial crisis 27,44 , $47-48$

and liberal capitalism's collapse 46,47 ,

$154,166,211$

and reregulation of financial sector 114

see also Keynesianism; Keynes, John

Maynard; the New Deal; World

Economic Crisis

The Great Transformation

defined 36, 78, 247

as emancipatory narrative $190,192-193$, 201

vs. 'fascist transformation' 176

and Freedom and Technology proposed sequel $14,128,132,133$

objectives 186-187

Polanyi's historical vantage point on 136-137

scholarly apparatus in 86

scholarly uptake of 135

summarized 180

see also Bennington Lectures; Polanyi,

Karl; specific concepts

Greenspan, Alan 216

(Financial Crisis Inquiry Commission, 2010) 44

guild socialism 5, 150, 177, 198, 204, 219, 233

Habermas, Jürgen 162

Halévy, Élie 140-141

haute finance

in Arrighi 232

as embedded international systems

96-97, 103, 105-106

and Lenin on imperialism 234

and peace 96-97, 105-106, 233-234, 235-236, 248n3

Hayek, Friedrich

and the Austrian School of Economics 22

and economic planning 15, 41, 161

on laissez-faire 145

and the London School of Economics

(LSE) 36

on Mises 163n4

monetary policy assumptions 61-62

and the neoliberal counter-revolution 7 ,

$21,23,41$

Hegel, Georg Wilhelm Friedrich 128

hegemony

as a problematical concept $82,83,233$
Arrighi's geometrical tool for 236-237, 236

British 47, 238-240, 245-246, 248n6

British and US compared 18, 245, 247

embeddedness 164, 238-240, 248n6

and failed states 53

financialization characterizes decline of 44-45

and globalization after fall of USSR 43

and the semi-periphery 240-241, 245

of US 38-41, 47, 53, 245

Heichelheim, Fritz 70-71

Herskovits, Melville 127

Hilferding, Rudolf 79, 95, 96, 235

Hirschman, Albert Otto 142-143

Hobson, John 95-96, 233, 235-238

'Homeland Security' 131

Hudson, Michael, 10-11, 77n3

Hui, K. and Hung, H.F. 244

Hundred Year's Peace

balance of power 96, 223-224

and haute finance 96-97, 106, 233-235, $248 \mathrm{n} 3$

ideational power 216-217

IMF (International Monetary Fund) 28, 54

Immerwahr, Daniel 2, 86

imperialism

Arrighi on problems of 233, 237-238

Arrighi's geometrical tool 235-238, 236, 246

and 'crustacean nations' $82,95-96$, 100-101

vs. hegemony 233

and Hobson's influence on Arrighi 233, 235-238, 236

and India 234-235

and Lenin's monopoly capitalism theory 95-96, 223-224, 233-234, 235-236, 248n 4

Polanyi and Marxist analyses compared 94-96

Polanyi's analysis of haute finance in backward regions 233-235

and state-capital fusion in world-systems theory 242-243

and world wars 223-224

impossibility theorem

and natural laws/laws of nature 142, 145, $149,150,159,160$

and rational planning in Mises 148-149

income distribution see inequality 
India

balance of payments with Britain 99, 246, 247

and British hegemony 240, 245-246, 247

colonial impoverishment of 234-235

cotton industry competition with

Lancashire 239, 246

and the gold standard 98-99

and world-wide capital accumulation 246

industrial revolution

as an English invention operating

globally 28-29, 245-246

China's 54

and laissez-faire 127

(machine age) material wealth gains from 46

moral and cultural implications of

139-140, 150-152, 160

the second industrial revolution 96

industrial society

and American exceptionalism 32

and digital technology $17,51-52,56-57$, 225-226

and disembeddedness 22, 256

and the failure of naturalism 144-145

and the mass consumption economy

226-227

and national sovereignty vs. free trade $52-53,98$

and nature $22,55,140$

and overview 5, 149-152, 161, 163n3

and the problem of a complexity 5 ,

148-149, 150-151

and processes of disembedding 22

trajectory and great transformation of 46-47

transformations in production 96 , 225-229

and war 246

Industrial Workers of the World 16, 52, $175,187-188 \mathrm{n} 4$

inequality

and post-Bretton Woods Reaganism/

Thatcherism 224-225

and coercion 220, 229

decline in (1910-1970) 222-224

depoliticization and naturalization of 220

and financialization 48, 55

global 126

and the mass consumption economy

crisis $226-228,228$

and the naturalization of unequal power 220
Piketty on inequality decline (1910-1970)

212, 213, 222

Piketty's solution to 221-222, 228-229

vs. predistribution $214-215,222-224$

redistributive approaches to 221,229

see also Capital in the 21st Century

information technology 51, 56

Inside Job (documentary) 116

instrumental rationality 162, 193, 196

interest rates $11,41,71,76$

Intermediate-Range Nuclear Forces Treaty 54

International Clearing Union 37, 83

international financial system 105-107, 234

internationalism 96-97, 237

International Karl Polanyi Society 189

international system, breakdown 30-32, 45, 82,103

International Trade Organization 49

investment

and declining inequality (Piketty) 222

declining in the real economy 43-45, 48, 55,107

and social reproduction 167-168

see also commodities; financialization; public goods

Isaac, Barry 259

jeopardy thesis 142

Johnson, Simon 50, 109, 116

jubilees 10

Kalecki, Michal 42

Keynesianism

and capitalism 157

consensus and productivity $40,42,47$

and the great transformation $36-38,41$

and mass consumption economy crisis 227

and the New Deal, 38, 157

'privatized' 227-228

Keynes, John Maynard

and the American Loan 38

and 'bancor' and International Clearing

Union 83

and Bretton Woods order 36-38, 40-41

and capital controls 37, 53

and crises 126, 136

on Marx's critique of Say's Law 90, 91

and Polanyi 81, 86, 89, 90, 91-93

on unpayability of post-First World War debts 61

Kindleberger, Charles 1 
Knight, Frank 126

Kondratiev, Nikolai Dmitriyevich 226

Kozul-Wright Richard 43

Kwak, James 109, 116

labour

as a fictitious commodity $55,89-90$, 162-163, 167

and capital 55

colonial organization of in India 234-235

decommodified under socialism 220

embedded in a specific social condition 238

exploitation of 52, 79, 86, 147, 162, 235

legislation as social protection 95

separated from land in capitalism 88 , 90

and technology 56

under feudal and mercantilist systems 62-63

labour theory of value $62,84-85,87$

Lacher, Hannes 13, 15-16, 136

laissez-faire

and American culture 165

and naturalism in classical political economy 143

and the neoliberals 145,160

in the US 156

was planned 31, 91, 147

Lamberg-Karlovsky, Karl 69, 72

La Nausée (Sartre) 132

land

and climate change 55-56

and the colonial organization of in India 234-235

as factor of production vs. fictitious commodity $55,88,90$

in feudal and mercantilist societies 62-63

Latin America, 54, 104, 114

Lausanne School (Walras, Pareto) 148

laws of nature see naturalism

League of Nations 101, 234

Lenin, Vladimir 95-96, 223-224, 233-234, 235-236, 248n 4

Leontief, W. 56

Levitt, Kari Polanyi 125

Lewis, John 178

Lewis, Sir Arthur 43

liberal society see nineteenth century civilization

liberal state interventions

and The Bank Act (1844) 92 to enforce self-regulating markets and create fictitious commodities 90-92

and establishment of laissez-faire capitalism 47

and the Federal Reserve Board (US) 41, 114-115, 117, 118, 216

to force money to behave like a commodity 90-92

and labour supply planning, 161

vs. naturalism in economic liberal thought 140-145

New Poor Law 216, 217

Old Poor Law 142

Poor Law Amendment Act (1834) 4, 31, 91

and private property vs. democracy 24 , 48

Say's Law 81, 86, 89, 90, 91

and tax havens for financial sector 119

see also 'Too Big to Fail' (TBTF)

liberal utopianism

and Bretton Woods order 164

and the double-movement 144-146

and false integration in capitalism 29-30

vs. global neoliberal utopianism 52

and ideas as drivers of institutional transformation 143

and the impossibility thesis inverted 145-146

and limitations of counter-movements against 147, 153

of Mises 150

and naturalism 144

vs. socialism 192-193

in the United States 165

L'institut français d'A frique noire 133

Lippmann, Walter 136, 139, 144, 145, 154-155

'Liquid Modernity' 50

London School of Economics (LSE) 36, 158

the long durée 242, 243, 244, 245, 247, 249 n 13

Long-Term Capital Management L.P. fund 116

The Long Twentieth Century (Arrighi) 231, $232,243,245-247$

Luther, Martin 130, 131

Luxemburg, Rosa 95-96

Maddison, Angus 46

Malthus, Thomas 82, 139, 140, 141

Mann, Michael 187-188n4 
markets

and instrumental rationality 162

as natural in neoclassical economics 90-91

regulations and predistributions necessary components of 221

as substitute for human relations in Mises 149

market societies

and freedom that kills 5, 14, 16, 17, 196-197, 202

local configurations and variability of 257

obsolete mentality of 137

and political-economic bifurcation 136, 161

reification in 202-203

and reproduction of society 167

Marshall Plan 39

'Marxism and the Inner History of the Russian Revolution' 33-34

Marx, Karl

Capital (Marx) 62, 79, 88, 107, 144, 230n3

on commodity fetishism 85,150

critique of Say's law 86, 89, 90, 91

influence on world-systems theorists 232 , 243,249 n 13

on land 62,88

Marxists on imperialism 94-96

and Polanyi on capitalism 85-86, 126

and Polanyi on fictitious commodities 87-88, 89-90, 107

and Polanyi's charge of economism 62, $84-85,144,235$

Polanyi's neglect of affinities with 217 , 255, 258-259

and the Ten Hours Act (1847) 217, 230n3

and Tönnies 87-88

mass consumption economy 226-228

Mendell, Margie 125

Menger, Carl 13, 22, 70, 126

Mirowski, Philip 41, 82

Mises, Ludwig von

abandonment of market naturalism 144-145, 148

'Economic calculation in the socialist commonwealth' 148

and Friedman 158

'Geneva Group' colleagues and milieu 22,48

and 'hard money' 61-62

Polanyian responses to $16-17,23$ on private property $24,48,197$

and socialist accountability debate

(complex societies cannot be planned)

$5,13,15,24,148-150$

modern political economy

Polanyi's contribution to modern 217, 219, 221, 229

revival of 211-212

monetary system breakdown after First

World War 61-64

money

and gold 61-62

in neoclassical economics 81,87

role of debt and credit in 63, 73-74

social character of 88-89

temple and palace origins of $65,66,69$, 70-74

token vs. fiat vs. specie $64,78,88,92-93$, 94

money as a fictitious commodity 9-13

defined 9-10, 88-91

and disembedding of economics from social context 74-77

and global inequality 55

latent in Marx 88, 89-90

Marx-Tönnies-Polanyi evolution of concept 88-90

and nationalism $80,94-95$

in Polanyi scholarship 80-81

a social institution $88-89,107$

money, commodified

as cause of crises in capitalism 91

and central banking 78, 93-94

defined 78

and deflation 92, 93

gaps in Polanyi scholarship on

$81-84$

and geopolitical economy 7, 78-79, 80, $81,93,98,232$

and the gold standard $61-62,78,81$, 93

and international haute finance

96-97

and the necessity of intervention 62 , 92-93, 100-101

political and international dynamics of, 91-93

restriction of supply $11,89,91-92,93$

and social protection in 'crustacean' nations 94-96

value relative to goods oxymoron 89

monopolies 47, 108-109

Mont Pelerin Society 41, 48, 158

Myrdal, Gunnar 41, 143, 151, 163n2,n5 
Nakayama, Chikako 17-18

'national cage' 43

National Commission on the Causes of the Financial and Economic Crisis (Final Report) 116-118

national economies and central banks 93-94

and the gold standard 98-100

and haute finance 105-107

nationalism

vs. cosmopolitanism in left thought 82

and informal empire in Arrighi 237

late industrializers vs. new nationalism 97-99

and politicized monetary policy 94

as social protection $9,31,53$

nations, and the international, scholarly confusion on 82

nation states

and 'Geneva Group' neoliberalism 49

and global economy 52-53

and globalization 43

and haute finance and government embeddedness 105

and imperialism in Arrighi 236, 237-238

and international free trade systems 30-32

(international order) moral and cultural implications of 139-140

(nationalism and national financial centres) and haute finance 97

and neoliberal weakening of as agent of redistribution 48

as 'shock absorbers' 53

and 'Too Big to Fail' (TBTF) financial institutions 108-109

'trilemma' 53

see also crustacean nations

naturalism

as basis for separation of economic and political 143-144

and economic liberalism 140-141, 149, $154,159,161,199,218$

and the impossibility theorem 142,145 , 149, 150, 159, 160

in Piketty's $r>g$ law 212-213, 229

and shifts in social consciousness

144-145

vs. social regulation/institutional reform $140-145$

survival of 155-156

naturalist fiction replacement by neoliberal fiction 159-163

and the two spheres (political and economic) 161

natural laws see naturalism

natural rights 141, 143, 161

nature

artificial relationship with 22, 29

and civilized life/society 57

and commodification of $55,63,82,90$, 91,258

and the double movement 35

free market threat to $29,57,152$, 179

neoclassical economics

vs. classical political economy 81-82, 90-91

and comparative advantage 81,86

and land, labour and money as commodities 55-56, 87, 89

markets as natural $90-91$

vs. Marx $81,84-85,88-89$

Polanyian failures to address 258-259

Polanyi's objections to $65,86,90-91,212$, 263-264

'Too Big To Fail' (TBTF) 109

see also Say's Law

neoliberalism

appropriation of society, rights and life, for markets 49, 160-162

and capitalism $45,46,48$

and commodified money 61-62

as counter revolution $41-45$

and the double movement 50-51, 154-155, 159-161

and economic geography field 251-252

fictions of 149, 159-160, 163n 4

and financialization $43-45,55,224-225$

The Geneva School variant of 48-50, 64-65, 161

and income inequality $213,219-222$

and mass consumption economy crisis 226-228

vs. nation states $48-49$

Polanyian case against 80

Polanyian failures to address 258-259

policies $42,47,221-222,229$

predicted outcomes of 47

and predistribution $217,221-222$

think tanks 41, 155, 158

triumph over Polanyi 48-50

see also deregulation; freedom in a

complex society; Mises, Ludwig von;

the Socialist Accounting Debate 
Neurath, Otto 24, 25, 148

the New Deal

pre-1940s perspective $172-176$

and a mass consumption economy 226

1940s 179-183

and big business vs. working class power

$176-177,182$

capitalist universalism vs. democratic socialism 176-177, 183-186

dearth of in TGT 169-170, 179, 187n1

and dictatorship of political powers

176-177

and embeddedness/disembeddedness 256

and (re)-embedding of markets 164, 165, 181

and fictitious commodities 181

and financial markets 32

and Keynes 38, 157

as non-socialist $181-183,188 \mathrm{n} 6$

Polanyi scholars on 'theoretical shift' 169-171

and property $16,180,181-182,188 \mathrm{n} 5$

and socialism 15-16, 26, 181-182

and socialism vs. capitalist reform

176-179, 180

and the US rise to world power 38-39,

157, 169-171

see also American exceptionalism

New Economic Archaeology 68-70

on the origins of money 70-73

and temple systems to manage debt 69-70

New Economic Sociology 135, 243-245

New International Economic Order 40, 49

new nationalism, and market economy failure 98-99

New Poor Law 216, 217

nineteenth century civilization

and capitalist great transformation 47

and classical liberalism in a complex society $140-141,148-150$

dynamic different after Second World

War in US 155-156

as failed civilization in TGT 136-137, 166

institutional bases of 4,136

and money-gold meanings 141-142

and self-regulating markets $4,47,78,90$, 136

uniqueness of $4,47,78,90,135,136$

for use of Polanyi concepts vs. neoliberal era $158-163$

and US interventionist state 156, 193
Nixon, Richard Milhous 41

Nobel Prizes (in economics) 41, 43, 116

No Exit (Sartre) 132

Non-Aligned Movement (NAM) 40

North, Douglass 244, 245

nuclear weapons 53-54

OECD, growth declines 43

Ohlin, Bertil 61

oil prices 42

Old and New Poor Laws 63, 234

On Freedom (Polanyi) 151

'On the nature and significance of economic science' (Robbins) 126

OPEC 40

Oppenheim, Leo 66, 72

Der Österreichische Volkswirt (Polanyi edited) $25,176,200,238$

Ottoman Empire 53

Owen, Robert 127, 137, 152-153

Palma, J. G. 44

Pareto, Vilfredo 13, 148

Paulson, Henry (Goldman Sachs CEO and Treasury Secretary) 105, 110, 117

Pearl Harbour attack 38-39

Peck, Jamie 18

periodizing and shifts 226-227

perversity thesis 142

Pettifor, Ann 7

philosophy, 'Manchester' vs. 'Westminster' of utilitarians 140

Piketty, Thomas see Capital in the 21st Century; inequality; predistribution

planning, as essence of economic activity (Robbins) 160-161

Polanyian economic geography

affinities with Polanyian economics 252-253

as a spacial-geographical theory $250-251$, 264-265

displaced/disembedded life produced embeddedness concept 254, 257

economic geographies 255 , 265-267

and embeddedness concept 254-255, 257

institutionalist comparative economy 256-257

and modes of integration 263-264, 266-267

pluralist potential of 253, 262-263

Polanyi's influence on the field 250-252

possibilities for development 259-265 
'terrain-level' theorizing 264

theory of geographically variegated economies 250, 262, 265-267

and uneven development/geography of embeddedness/disembeddedness 256

a 'world life' shaped by the great transformation of 20th century history 253-254

Polanyians economic geography, overview 250-251

Polanyi Archive 125

Polanyi, Ilona Duczyńska 25-27, 127, 255, 257

Polanyi, Karl

as an alternative to economic reductionism 259-263

best-known unknown intellectual, 189, 258

biography 3, 23-27, 127, 136-137, 257

contemporary relevance of 21-23, 27, $137,138,158-163$

as economic anthropologist 243

'General Economic History' course (Columbia) 1, 22, 125, 126-127, 251

influence on Assyriology 66-68

influence on social and political thought $17-18$

influence on world-systems theory 18 , 231-232

institutionalism of $151,229,251$, 261-262

intellectual formation through personal displacement 253-259

on Marx's adherence to classical liberal economics 35-36

misinterpretations of his views on Marx 25

misinterpretations of his vision of society 136, 152-153, 166, 170

neo-Polanyians 171,177

rediscovery of 1-3

scholarly applications of his concepts $135,137-138$

theory of history 166-169

vision of international coexistence 54 , 55

Polanyi scholarship

gaps $80-84$

interpretative issues $22,84-87$

The Poor Law Amendment Act (1834) 4, 31,91

Popper, Karl 142 post-industrial society $17,51-52$, 225-228

pound sterling $28,31,36$

predistribution

challenges economy-politics binary 215

and coercive power of the state 217, 229

to decrease inequality (1910-1970) 223

defined as pre and post-tax outcomes politically determines 215

and deregulation 220-221

vs. dualistic separation of politics and economics 214-215

and the fallacy of market freedom 220

and fictitious commodities 215-216

and historical shifts in income

distribution 222

and intellectual property laws 217

and legal realists 216

and the naturalization of inequality 220 , 229-230

and neoliberalism 227

vs. Piketty's r>g 214-220, 229

vs. primary market distribution and redistribution 215

and redistribution 214-215, 223

as weapon against neoliberalism 221-222

and workers 221

see also inequality; Capitalism in the 21st Century

prices

in market economies 108

and debtors vs. rentier interests in selfregulating markets 63-64

and fictitious commodities 10, 87

of framework goods 199

in free market systems 103, 108

and gold standard impact on defeated nations 28,31

in the Socialist Accounting Debate 24-25

and social reproduction 167

private property

and credit/debt arguments 73

and the 'Geneva Group' 24, 48, 197

and globalization vs. national regulation $42-43$

and international trade agreements 49 and the limited franchise 47

regulated (in Polanyi) 170

see also commodities, money; fictitious commodities; money; money as a fictitious commodity; specific liberal theories 
production

and fictitious commodities 146

and importance of periodization and production shifts in 212, 226-227

and post-industrial term in Polanyi 225-226

investment in the real economy $43-45$, 48,55

proportion of GDP vs. financial sector 116

public choice theory 221

public decision making 56

public equity 55

public goods $47,51,52,53,55,62-63$

public works 36,38

Quantitative Easing 76, 117

Reagan administration 42, 220, 224, 227

Reagan, Ronald Wilson 42

Red Vienna 24, 48, 197

re-embedded markets

danger of embedding society into markets 164

with dollar/gold standard (Glass Steagall Act) 103-104

in financial sector 10, 108-109, 114

as impairment to market functioning 167

misinterpretations of 164-165

and the New Deal 170-171

and Polanyi's redistributive economy 15,66

post-Second World War institutions in America 164-166

and TBTF after Third World debt crisis 104,114

and US Treasury Secretaries by sector 104-105

regional planning vs. universal capitalism 5 , $9,137,155$

reification, in market society 202-203

Reinhart, Carmen 136

Renger, Johannes 65, 66

rent, in Capital 62-63

rentiers $28,36,38,44-45,49,62-63$

revelations

conscience/soul, inner life and freedom 130,131

as dialectical shifts in social consciousness 128

and industrial society 129,131

revelations knowledge of death (first revelation) 129-130, 131 revelations social consciousness (the second revelation)

and classical economics 142-143

as driver of institutional transformation $143,163 n 5,196$

linked to social forms 128

vs. market mentality 192-193

shifts in $129,132,144-145,195-196$

and technology 139-140

revelations 'reality of society' (third revelation)

concept genesis $14,127-128$

defined 132, 151-152

and the double-movement $13,127,163$

and freedom in a complex society 17 , 198-200, 204-205

and reform of human consciousness 151

$r>g$ (rate of return exceeds economy's annual growth rate) $212-213,214-220$, 229

Rhetoric of Reaction (Hirschman) 142-143

Ricardo, David

and commodification of money 88,89

and double-movement 139, 140

and the gold standard, debt and trade relationships 61,98

on laws of distribution and nature 140

vs. Mises 149

vs. modern theorists on foreign debts 73

Polanyi's criticism of $29,64,81,82$

Riesman, David 225

The Road to Serfdom (Hayek) 41

Robbins, Lionel 15, 36, 48, 126, 154-155, 157, 160

Robinson, Ronald 96

Rodrik, Dani 2, 21, 43, 52-53

Rogoff, Kenneth 136

Roosevelt, Franklin Delano and Bretton Woods conference (1944) 39

and the New Deal 38-39

and reform of US capitalism 176-179

State of the Union address (1944) 39

and trade unionism 176-178

Rostow, W.W. 54

Rothschild banking dynasty 96, 106

Rotstein, Abraham 1, 13, 14, 17, 86, 134n1

Roubini, Nouriel 56

Rousseau, Jean-Jacques 203

RSTF ('right size to fail') financial institutions 103, 109, 110-111, 111, 114 
Rueff, Jacques 61, 154

Ruggie, John Gerard 83, 103, 164

Russian Revolution 33-34, 49-50, 144-145, 196, 223, 254

Russo-Japanese war 52

Sartre, Jean-Paul 132

Say, Jean-Baptiste 139, 141

Say's Law 81, 86, 89, 90, 91

scarcity, as existential fact of economic life 126-127

Schumpeter, Josef Alois 22, 50, 226, 232, 243

Scott, Frank 125

self-regulating markets and The Bank Act (1844) 92

defined 103, 108

as defining institution of nineteenth century society $4,47,78,90,136$

vs. democratic society $75,181-182$

and disembeddedness 108, 244, 256

exceptions to $108-109,110$

and fictitious commodities 90-91, 146, 225

and fictive disregard for institutions 141, $143,217,260$

and the gold standard 98-100

impact of enfranchisement on 168

and nation states 94-95

and social protection as impairments to $167-168$

and social protection movements against $75,91,100,146-147,181,189,198$, 211

and social reproduction 167-168

and systems theory $108,110-111$

and the transformations of industrial production 225-229

unnaturalism of 47,90

use of state power to maintain 90-91, $100,214-215$

vs. US protectionism 156-157

as utopian project $4,30,52,144,146$, 198

separation of politics and economics (disembeddedness) and imperialism and capitalism 95-96

Seven Years' War 96

shareholder value vs. long-term profitability 43-44

Silver, Beverly J. 231

Slobodian, Quinn 48

Smith, Adam 46, 88

Snowden, Edward 131 social class

differentiation of workers and professional middle class (cultural divide) 51

and gold standard 36

relations in the US 172, 173-176, $187-188 \mathrm{n} 4$

social contract $37,40,42$

social democracy

as a counter-movement and failures of 50-51

contemporary failures of 50,52

social integration

defined 51

vs. false integration $29-30,50-51$

vs. free market ideology 62-63

modes of 266-267

and nation states in global economy 52-53

and the US 180

socialism

absence/possibilities of in US 165-166, 174-177, 183-186, 187-188n4

through 'crustacean nations' 78-79, 101

and the double movement $74-75$, 200-201

as freedom and responsibility 189,202 , 203-204

necessity of 55-57, 139, 155, 181, 196-197, 219

and Polanyi scholars 135, 136

Polanyi's vision of 5-6, 9, 15-16, 17, 26

'theoretical shift' interpretation of $170-171,178$

and trade unionism 176-178

and the welfare state $6,164,170-171$, 186

see also freedom in a complex society

Socialism (Mises) 148

Socialist Accounting Debate 15, 24, 148, 198-199, 219

socialist democracy for combatting neoliberalism and income inequality 219-222

social protection

against fictitious commodities 95

against unemployment 100

and central banks 93-94

and the collapse of nineteenth century civilization 147

and the conservative/propertied class 153

and 'crustacean nations' 78, 100-101

and depression 176

in the double movement (defined) 75 
social protection (cont.)

vs. laws of nature 140-141

limits of 147, 153

market regulation as 62

misinterpretations of 153

and national currencies 95

vs. neoliberal market solutions 159

non-democratic forms of 167-168

and social reproduction in market society

167

vs. social subordination to markets 190

in the US 173

see also 'crustacean nations'; the double movement; 'Too Big to Fail' (TBTF)

Social Structures of Accumulation scholars 226

'social value' 148

Sombart, Werner 143, 166, 174-175, 188n 4

Somers, Margaret R. 2, 6, 17, 35, 80, 138, 171, 188n6, 208, 230n1, 248n2

South-South cooperation 54

Speenhamland laws 80, 139

spheres (political-economic separation)

breakdown of 29, 161

in classical political economy 214

and dictatorship of the political powers in the US 176-177

empirical vs. ideological/ ambiguities in Polanyi 216

and liberal utopianism 216

and neoliberal behavioural assumptions 161

vs. Polanyian predistribution 214-215

vs. Polanyi's institutional approach to economy 214

Polanyi vs. Piketty on 212-213

and predistributional 'firewall' in favour of capital 217, 219

separation of in the US 173

working at odds 168

Stalin, Josef 175

state power

as coercive and predistributive $216-218$, 229

predistribution legislation in response to counter-movements 217

predistribution through freedom of contract 215,218

Sterling Bloc 37-38

Sterling Standard 93, 98-99, 142

The Stranger (Camus) 132

Streeck, Wolfgang 43, 49-50

structural adjustments

and the IMF 28 and post-war Britain 37

and the US dollar-gold convertibility 41

substantivism 126-127, 226, 243, 260-261

alternative to reductionist formal economics 226, 258, 259-260

and importance of type of production 212, 225-229

supply and demand

and the market as a natural phenomenon

in classical liberal value theory 141

and neoliberalism 161

and social reproduction 167

systems (theory) defined 108, 110-111

Szelenyi, Iván 170

TARP (Troubled Asset Relief Program) $110,112-113,114,117$

taxation

contribution (value added) of US financial sector 118-119

and neoliberalism 42, 47

pre-tax and post-tax in Piketty 213

and public services 47

and Reagan administration 42

regressive sales taxes 42

technological society

and the counter-movement 152-155

and Keynesianism 157

and the limits of social protection 153

and the neoliberal fiction 159-160

overview/freedom problem 5, 149-152, 161, 163n3

and the problem of freedom and responsibility $148-152$

and the problem of knowledge 149

and the utopianism of post-war doublemovement (international market with national protection) 157-158

and welfarism 158

technology

and civilizational consciousness shifts 129,132

and counter-movements 147

dependence on and vulnerability to 14 , 131,133

and the emergence of economic liberalism 139

existential challenge of $56-57,129,131$, 132

and freedom of consciousness (inner

freedom lost) 131-133, 140

and full employment 57 
and inner freedom lost 132

institutional containment of 132

and mass consumption society 40

and 'the reality of society' 151-152

and tacit consent to unlimited state power 131

Ten Hours Act (1847) 217, 230n3

Thatcher, Margaret Hilda 42, 62, 75, 220, 224, 227

thick description 260

Third World Debt Crisis 104, 114

Thomasberger, Claus 6, 13-15, 85, 189, 192, 204, 207

Thurnwald, Richard 255

TINA (there is no alternative to capitalism) 42

token money, vs. commodity money 93

Tönnies, Ferdinand 10, 11, 13, 35, 86-87, $89-90,152,255$

and embeddedness 255

and society vs. community 204

'Too Big to Fail' (TBTF)

as a (re)-embedding process $12-13$, 102-104

asset values of 109, 113

and bank rescue programs $110,112-113$, 114

vs. disembedded 'right size to fail' (RSTF) 103, 109, 110-111, 111, 114

embedded in Federal Reserve Board (US) 114-115, 117, 118

embedding of 108-109, 120-121

and financial consolidations 109, 112,

118,118

as non-competitive exceptions 108-109, 110

Townsend, Joseph 140

trade deficits 247

trade unionism

as a counter-movement 50, 223

neoliberal predistributive war on 220

and predistribution 216

pro-imperialist vs. socialist tendencies 177,181

in the US 40, 176-178, 181, 188n4

trentes glorieuse (1945-1975) 211, 226

'trilemma' 53

Troubled Asset Relief Program (TARP) $110,112-113,114$

Trump, Donald (presidency) 7, 51, 54, $105 t$

Turkey 53

Turner, Frederick Jackson 174

TVA (Tennessee Valley Authority) 176, 181
Ugarteche Galarza, Oscar 10, 12-13

UNCTAD Trade and Development Report (2017) 43

unemployment $36,38-39,42,56,61,100$

uneven development 79, 232, 250, 256, 262-266

United Auto Workers 178

United Nations 39, 49-50

United States

as a 'crustacean nation' 83

as a declining hegemon (dangers)

53-54

attachment of people to the social order $175,187 \mathrm{nn} 3-4$

class and social status in $174,176-178$, 182

constitution and society in 156 , 172-173

economy compared to China and Asia 46

and the great transformation 176

military-industrial complex 39, 115

possibility of democratic integration of 180

post-war dominance in world economy 37-41, 61, 83, 155-158

and post-war restoration of capitalism 183-186, 188n7

Republican Party 32, 41, 185-186

revolutionary potential of $175,187 \mathrm{n} 2$

space (land) vs. social rights in US 173 , 180

USSR relations $30,184-185$

and the Vietnam War 18, 39, 83, 245, 247

United States dollar

and the Glass Steagall Act 103-104

as international reserve currency 41,83

and Marshall Plan 39

universal capitalism

vs. 'crustacean nations' $78-79,101$

vs. democratic socialism $183-186$

vs. regional planning 5, 9, 137, 155

US restoration of 164-165

USSR (Union of Soviet Socialist Republics) $39,43,185,241$

usury

cancelation of debts for economic stability 69

as feudal 62

to obtain dependent labour and small-

holder land 76

regulation of in antiquity 68

utilitarianism 56, 140, 144 
utility 161

utopianism in neoliberalism 159-160

value production $84,85-86$

value relative to goods oxymoron 89

Vietnam War 18, 39, 83, 245, 247

Volcker shock 41, 42

Von Bertalanffy, L. 108, 111

Wagner Act (1935) 178

Waiting for Godot (Beckett) 132

Wallerstein, Immanuel 231, 232, 240, 241-242, 248n2

Wall Street 176, 233

Walras, Marie-Esprit-Léon 13, 148, 162n1

WEA/IEE (New Deal) 176

weapons of mass destruction 53-54

Weber, Max 13, 232, 236, 243, 251

Weekend Notes 125, 127-128

welfare state

in Britain 38, 80

neoliberal critique of 158,160

and Polanyian socialism 6, 164, 170-171, 186

utopianism of $157-158$

welfarist school 148, 157

see also the New Deal

Western society disembeddedness 74-77

Wieser, Friedrich 148

Wilson, Woodrow 101, 234

Wittfogel, Karl 68

Workers in an Integrating World (World Development Report of 1995) 42-43

working class

in Britain 172

and colonialism 224

and deindustrialization 51-52

enfranchisement impact on market system 168 and the Hundred Year's Peace 223-224

illiberalism and the double movement

51

in Marx vs. Polanyi 62

and neoliberalism 42-43

and the precarity of work 45, 51, 56, 216

remuneration compared with managers $36,43-44$

and Sombart 174-175, 187-188n4

in the US 172, 173-178

weakness of 166, 169, 176, 178, 225-226

World Development Report (1995)

(Workers in an Integrating World) 42-43

World Economic Crisis (1929-1933) 21-28, $27,47-48,103,226$

world economy

as a hierarchy of production and power 82

and haute finance 105-106

world production, historical overview 46-48

world-systems theory

and Braudel's influence on Arrighi 232, 240, 241-243, 244, 248, 249n13

capitalist reconstruction and globalization 240-241

contextualization of Polanyi in economic sociology 243-245

embeddedness and British hegemony $238-240$

and haute finance and non-economic influences 233-235

on imperialism 232, 233, 235-238

the long durée 242, 243

Polanyi's influence on 231-232, 245-247, $248 \mathrm{n} 2$

semi-periphery concept 240-241, 245

world capitalist system origins 242

World Trade Organization (WTO) 49 